\title{
Autologous Stem Cells and Transmyocardial Laser Revascularization for Ischemic Heart
}

\author{
Esha Ibrahim ${ }^{1}$, Quan Zhu ${ }^{1}$, D. Glenn Pennington ${ }^{1}$, Charles E. Ganote ${ }^{2}$ and Race L. Kao ${ }^{*}, 1$ \\ Department of Surgery ${ }^{l}$ and Department of Pathology ${ }^{2}$, James H. Quillen College of Medicine, East Tennessee State \\ University, Johnson City, TN, USA
}

\begin{abstract}
Myogenic stem cells and transmyocardial laser revascularization (TMR) have been used independently to treat patients with coronary heart disease. We assessed the hypothesis that implantation of autologous myogenic stem cells during TMR will augment ventricular function by new muscle formation and will improve perfusion by neovascularization. Thirty two mini-swine were subjected to myocardial ischemia by applying an ameroid constrictor on the left anterior descending coronary artery. Pigs were randomly assigned into four equal size groups of Ischemia, Ischemia+TMR, Ischemia + Cell and Ischemia + TMR + Cell. Myocardial blood flow was estimated using colored microspheres, 12 lead ECG was recorded, and ventricular function was determined by the hemodynamic system coupled with sonomicrometry. Three weeks after ameroid constrictor application, ECG changes indicated myocardial infarction of left anterior and apical areas in all pigs. Significant decreases $(\mathrm{P}<.01)$ in systolic \% wall thickening fraction and \% segmental shortening fraction were also observed. At 9 weeks after initial surgery a dramatic decrease $(\mathrm{P}<.01)$ in scar areas, a marked improvement $(\mathrm{P}<.05)$ in myocardial perfusion and significant better hemodynamic functions were observed for cell implantation groups. Labeled muscle tissue was observed at the implantation sites. Systolic \% wall thickening fraction and \% segmental shortening fraction were also clearly improved in the cell implanted groups. Stem cells alone or TMR+Cell significantly reduced scar areas, developed new muscle tissue, improved myocardial perfusion, and enhanced contractile function after myocardial infarction.
\end{abstract}

\section{INTRODUCTION}

The possibility of direct revascularization of the ischemic myocardium with laser was initially suggested in 1981 [1]. Early clinical results suggested improved myocardial perfusion without significant changes in global and regional contractile functions $[2,3]$. The original hypothesis of myocardial perfusion from the laser channels was not supported by recent experimental and clinical studies which indicated the lack of myocardial sinusoids in humans, the higher myocardial than ventricular pressure, and the rapid occlusion of laser channels [4 -7].

Transmyocardial laser revascularization (TMR) is an emerging treatment for patients with medically refractory angina who are not amenable to coronary artery bypass grafting or angioplasty [6-9]. The clinical and experimental data suggest that the likely mechanisms for improvement are modification of cardiac nervous system [10-12] and angiogenesis induced by growth factors production after myocardial injury and inflammation $[7,13,14]$. From the prospective randomized multi-center trials, TMR significantly reduced severity of angina, improved quality of life, increased exercise tolerance, decreased hospitalization, and improved clinical status $[7,8,15,16]$. Even though the exact beneficial mechanisms of TMR are not clear at this moment $[15,16]$, TMR has been approved by Food and Drug Administration (FDA) for clinical usage and is a reimbursable procedure by insurance companies because of its obvious clinical advantages. A recent clinical trial using Ho:YAG laser has

*Address correspondence to this author at the Department of Surgery, East Tennessee State University, P.O. Box 70575, Johnson City, TN 37614, USA; Tel: 423-439-8803; Fax: 423-439-8750; E-mail: kao@etsu.edu indicated that the placebo group had the same results as the laser treated group after two years [17]. However, multicenter prospective randomized trials of no-option class IV patients at 5-year follow-up have demonstrated a benefit of survival and angina relief by Ho:YAG laser TMR [18]. In addition when Ho:YAG laser TMR was used as an adjunctive procedure with coronary artery bypass grafting for incomplete revascularization due to diffused coronary disease, the 5-year follow-up results indicated superior angina relief [19].

Both the $\mathrm{CO}_{2}$ laser and the Ho:YAG laser are FDA approved for clinical usage. However $\mathrm{CO}_{2}$ laser with the wavelength of $10.6 \mu \mathrm{m}$ is more efficiently absorbed by water molecules than the Ho:YAG laser (wavelength $2.1 \mu \mathrm{m}$ ). Furthermore, the PLC Medical Systems $\mathrm{CO}_{2}$ laser (Franklin, MA) can make a transmyocardial channel with one pulse while the Ho:YAG laser (Cardiogenesis, Foothill Ranch, $\mathrm{CA})$ will require multiple pulses and some mechanical energy. The clear advantages of TMR using the $\mathrm{CO}_{2}$ laser are also supported by the objective data and 5 years of symptomatic improvement $[15,16,20]$. TMR using a $\mathrm{CO}_{2}$ laser (PLC Systems) applied at the effective channel density $[21,22]$ was used for this study.

We have been using autologous satellite cells from skeletal muscle for myocardial regeneration studies in dogs since 1989. Satellite cells have been successfully isolated, labeled, and implanted into injured hearts with significant improvement in contractile function, formation of muscle tissue and reduction of scar in the animals having successful cell transplantation [23-26]. Similar results following implantation of autologous skeletal myoblasts (satellite cells) into experimental animals for myocardial repair and functional improvement has been confirmed by other investigators [27]. 
The advantages of using autologous satellite cells as compared to other stem cells are further supported by recent publications [28,29]. Highly encouraging clinical results have been published by others [30-35] and from our observations [36,37]. Although the survival of transplanted satellite cells as well as the feasibility and safety of clinical application have been observed in long-term follow-up studies [38,39]; the definitive long-term efficacy requires large scale, placebo-controlled, double-blind randomized trials [40].

By replacing, repairing, or enhancing the biological function of damaged tissue or organs, cell therapy has emerged as a strategy for the treatment of human cardiac diseases [41]. Satellite cells have been shown to regenerate skeletal muscle in all ages and species of mammals that have been investigated [42]. Using autologous satellite cells to replace the lost heart muscle cells and local expression of angiogenic factors to improve perfusion of the ischemic myocardium after TMR may provide an additive benefit and enhance clinical outcomes over either procedure alone.

\section{MATERIAL AND METHODS}

\subsection{Experimental Animals and Surgical Preparation}

Thirty two male mini-swine weighing 25 to $30 \mathrm{~kg}$ were purchased (Harlan-Sinclair, Indianapolis, IN) for the proposed study. Swine were selected based on their similarity in cardiovascular system to humans and the success of our preliminary studies. Pigs were randomly assigned into four groups of Ischemia, Ischemia + TMR, Ischemia + Cell and Ischemia + TMR + Cell with eight pigs per group. After fasting and preoperative antibiotic treatment, atropine $(0.05$ $\mathrm{mg} / \mathrm{kg}$ ) was given before anesthesia was induced with telazol $(4.4 \mathrm{mg} / \mathrm{kg})$ and xylazine $(2.2 \mathrm{mg} / \mathrm{kg})$ by intramuscular injection. Lactated Ringer's solution was given through a catheter inserted into the ear vein. Following intubation with a cuffed endotracheal tube, anesthesia was maintained with isoflurane ( $2 \%$ to $4 \%$ ) using a mechanical ventilator. After shaving the surgical sites and cleaning them with alcohol, the electrocardiogram (ECG) was monitored by the PageWriter Cardiograph (Hewlett-Packard Co., Andover, MA) while the body temperature was recorded by a rectal probe (Yellow Springs Co., Yellow Springs, OH). Following preparation of the surgical area with Betadine, arterial and central venous pressures were recorded using Millar pressure transducers (Millar Instruments, Inc., Houston, TX). This study conforms to the "Guide for the Care and Use of Laboratory Animals" published by National Institutes of Health (No. 85-23, revised 1996) and approved by the University Committee on Animal Care of East Tennessee State University.

\subsection{Isoaltion and Culture of Sattellite Cells}

Swine were anesthetized and prepared for a sterile surgical procedure to obtain samples $(\sim 10 \mathrm{gm})$ from the longissimus dorsi muscle. The muscle sample was rinsed in $70 \%$ ethanol followed by three rinses in Hank's balanced salt solution without $\mathrm{Ca}^{++}$and $\mathrm{Mg}^{++}$but containing $1 \%$ of penicillinstreptomycin. The tissue was minced $\left(\sim 1 \mathrm{~mm}^{3}\right)$ before being incubated with $50 \mathrm{ml}$ of enzyme solution (1\% collagenase and $0.2 \%$ hyaluronidase). After 15 minutes of incubation at $37^{\circ} \mathrm{C}$, the satellite cells were harvested by pouring the solution through layers of sterile gauze into a sterile container and pelleted by centrifugation. The remaining tissue was incubated for another 15 minutes in enzyme solution to complete the release of satellite cells from muscle as our previous publications [23-26].

The isolated satellite cells were washed with medium 199 containing serum (10\% fetal bovine serum) and 1\% antibiotic antimycotic solution (Sigma Chemical Co., St. Louis, MO) for 3 times by centrifugation ( $650 \times \mathrm{G}$ for 10 minutes) and resuspension. The viability of isolated cells was checked by trypan blue exclusion and the cell number was counted using a hema-cytometer. After proper dilution, 1 x $10^{6}$ cells were cultured with $8 \mathrm{ml}$ of proliferation medium in a $25 \mathrm{~cm}^{2}$ culture flask. The culture medium was changed twice every week and the satellite cells were maintained at low density (by sub-culture) for continued proliferation without differentiation. A typical picture of the cultured satellite cells is shown by Fig. (1A). To verify the myogenic capability of the cultured satellite cells, a portion of the cells were cultured in differentiation medium and the formation of myotubes were observe for all samples as reported before $[25,26]$.

\subsection{Labeling of Cultured Cells with Humanized Green Fluorescence Protein (hrGFP)}

Three days before the satellite cells were harvested for transplantation, regular medium was replaced by culture medium containing pFB-hrGFP retroviral supernatant (Stratagene, La Jolla, CA, USA). The concentration of pFBhrGFP retroviral supernatant stock solution was about $2.7 \mathrm{x}$ $10^{7}$ transducing virions $/ \mathrm{ml}$. After proper dilution (100:1 multiplicity of infection) with the medium, it was used following routine procedures. At 8 hours later regular medium was used to wash the cells and replace the labeling medium. After 24 to 48 hours following exposed to labeling medium, the GFP could be easily observed in more than $80 \%$ of cells under a fluorescent microscope with the fluorescein isothiocyanate (FITC) filter. A fluorescent micrograph showing the labeled satellite cells is presented by Fig. (1B).

\subsection{Ischemic Injury, TMR and Implantation of Autolo- gous Satellite Cells}

Under full anesthesia and sterile surgical conditions, the heart was exposed through a partial sternotomy. After intravenous administration of lidocaine $(2 \mathrm{mg} / \mathrm{kg})$, a segment of the left anterior descending coronary artery (LAD) just below the first diagonal branch was dissected free for placement of an ameroid constrictor (2.5 mm internal diameter; Research Instruments SW, Escondido, CA) and ultrasonic flow probe around the vessel. The flow probe was placed down-stream from the ameroid constrictor. The freed LAD was occluded for 5 minutes to ensure comparable ischemic area $(\sim 30 \%$ of left ventricle) produced in each animal. The borders at the middle of ischemic area were marked with 6-0 Prolene sutures to guide myocardial sampling after termination. At the end of the study (nine weeks later), all ameroid constrictors were retrieved from the heart and inspected to confirm vessel occlusion.

Three weeks after ameroid constrictor placement, while under sterile surgical preparation and following hemodynamic evaluation, the heart was exposed through a partial sternotomy. TMR was performed with an $800-\mathrm{W} \mathrm{CO}_{2}$ laser (The Heart Laser, PLC Medical Systems, Franklin, MA) using a single $20-\mathrm{J}$ pulse timed to the R wave of the ECG. 
Twenty channels were created at $1 / \mathrm{cm}^{2}$ covering the ischemic myocardium (LAD perfusion area). After TMR and establishment of hemostasis, $0.1 \mathrm{ml}$ (containing $\sim 2 \times 10^{6}$ cells) of GFP labeled autologous satellite cells were injected at the center of each channel through a 25-gauge hypodermic needle. The depth was controlled by a plastic disc fixed on the needle and a short piece of PE 10 tubing covering the end of needle to ensure injection into the channels. The TMR animals were subjected to the same treatment but serum free culture medium was used. The Cell group was injected with the same volume and number of cells at identical density (1injection $/ \mathrm{cm}^{2}$ ). The Ischemia group only had a partial sternotomy.
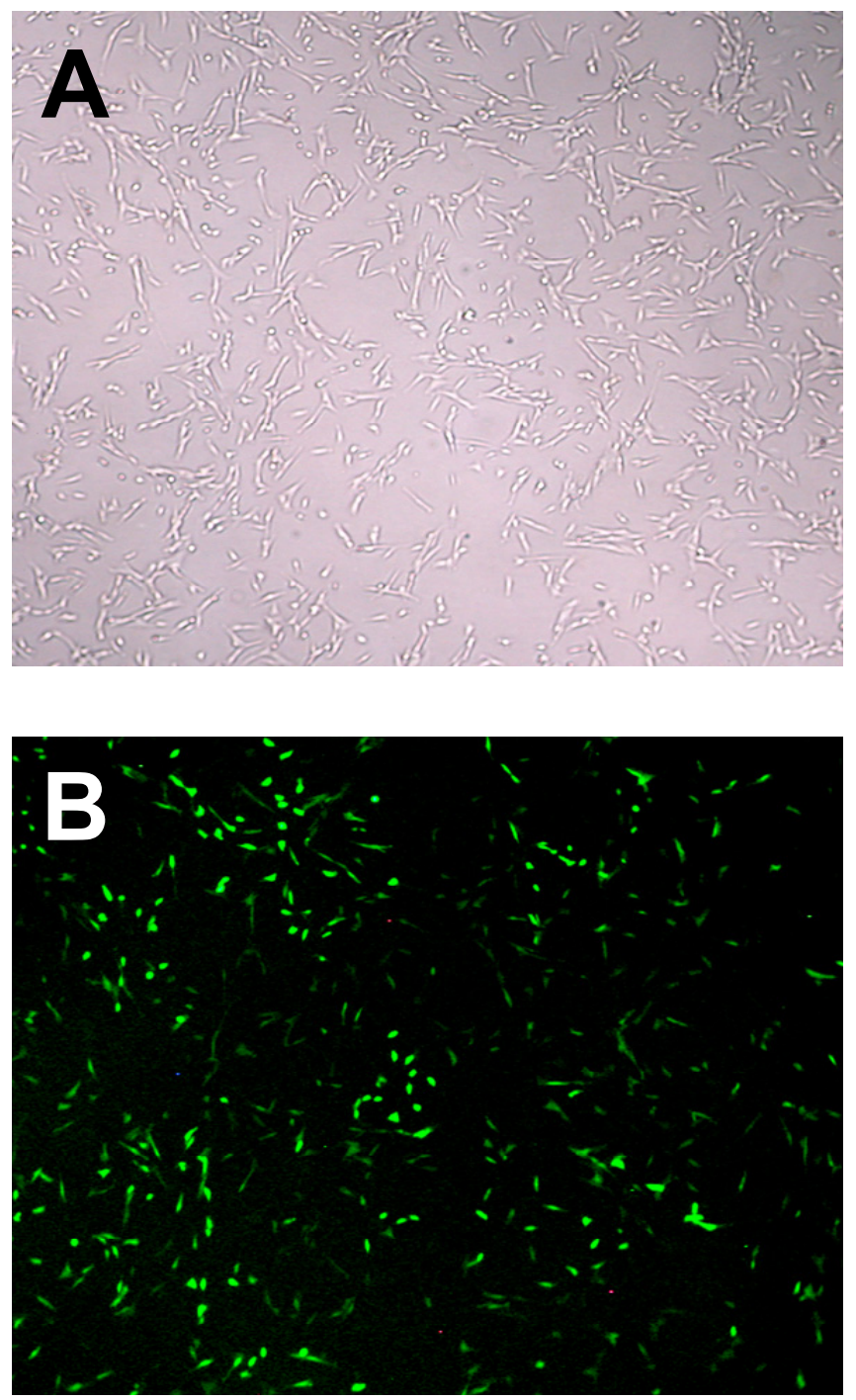

Fig. (1). Cultured and GFP labeled satellite cells. Satellite cells in culture (A) and cultured satellite cells after labeled with pFBhrGFP (B). More than $80 \%$ of cells are expressing GFP at 24 hours after labeling.

\subsection{Hemodynamic Evaluations}

The left ventricular, aortic and venous pressures were determined using Millar pressure transducers. The electrocardiograms were recorded using the PageWriter Cardiograph. The pressures, ECG, pressure length loops, and pressure volume loops were integrated using the computerized VF-1 hemodynamic system (Data Science Inc., St. Paul,
$\mathrm{MN}$ ) and the Digital Sonomicrometer (Sonometrics Co., London, Ontario, Canada). Implantable ultrasonic crystals were secured to the heart (Fig. 2) at the long axis of the heart (1 2), short axis of the heart (3 4), across the depth of the left ventricular free wall $(\mathbf{3} \sim \mathbf{5})$, and at the border of the ischemic area (6 7). Their ends were exteriorized through separate stab wounds in the intra scapular region. A skin button which allowed the healing and impermeable sealing of the skin wound was used as the connection for the instrumentation during the entire study.

The pressures, $\mathrm{dP} / \mathrm{dt}$, heart rate, cardiac output, pressure length loops, pressure volume loops, left ventricular volume, ejection fraction, systolic percent thickening fraction and percent segmental shortening fraction were used to determine the global and local contractile functions. The load independent indices (Emax and Tau) were obtained by temporarily occluding the vena cava and recording the pressure volume loops after releasing the occlusion (Fig. 3). The systolic percent wall thickening fraction (\%TF) and percent segmental shortening fraction $(\% \mathrm{SF})$ were calculated by the following formulae.

\section{For \%TF:}

Distance between crystals 3 to 5 at end systole - distance at end diastole

Distance between crystals 3 to 5 at end systole $-\mathrm{X} 100 \%$

For \%SF:

Distance between crystals 6 and 7 at end diastole - distance at end systole

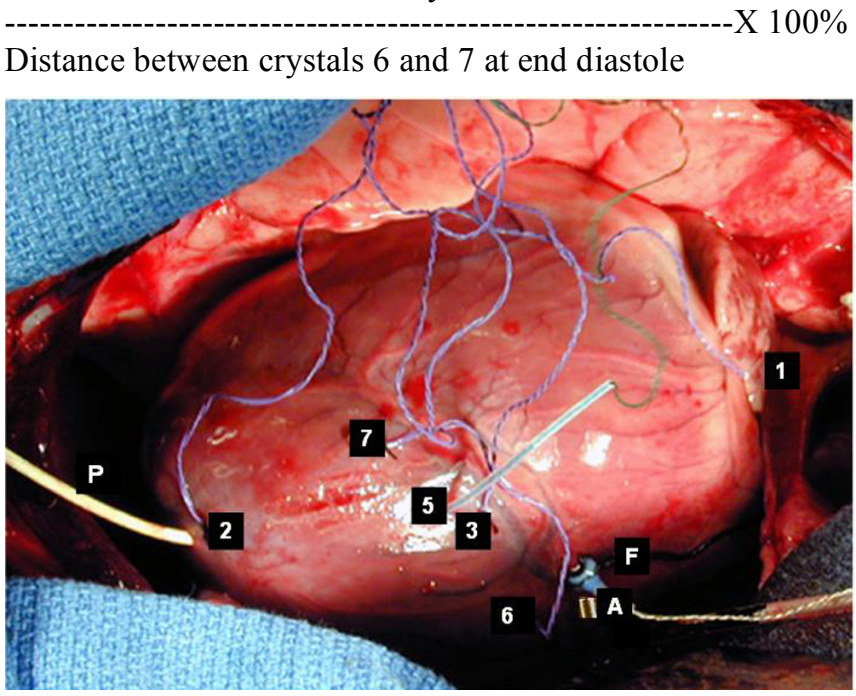

Fig. (2). Instrumentation of the pig heart. Number 1 to 7 indicates the location of the ultrasound crystals. Number $\mathbf{4}$ is below the heart directly against $\mathbf{3}$. The distance between $\mathbf{1}$ and $\mathbf{2}$ is the long axis of the heart. The distance between $\mathbf{3}$ and $\mathbf{4}$ is the short axis of the heart. The changes in distance between $\mathbf{3}$ and $\mathbf{5}$ during cardiac cycle are used to calculate the \% wall thickening fraction. Crystals 6 and 7 are located at the border of the ischemic area and the changes in their distance are used for \% segmental shortening calculation. $\mathbf{A}=$ ameroid constrictor, $\mathbf{F}=$ flow probe, $\mathbf{P}=$ pressure transducer. Adequate clearance is made below the ameroid constrictor to ensure its installation will not interfere with normal coronary flow as determined by the flow probe. 


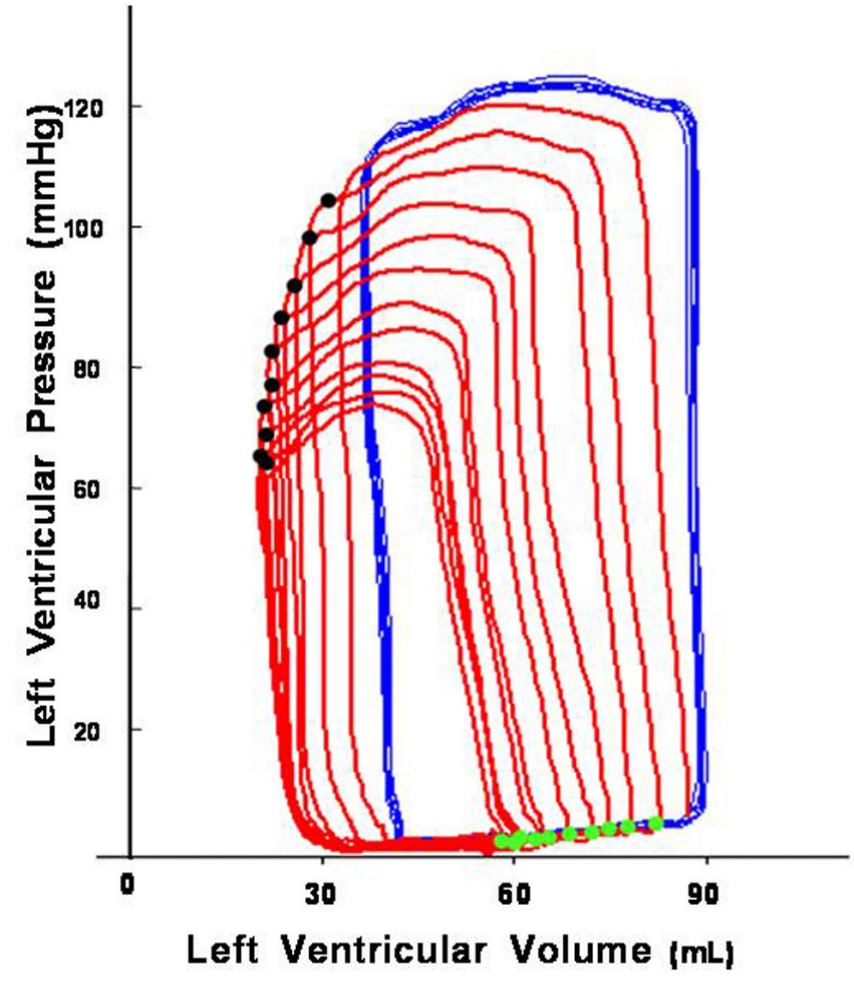

Fig. (3). Pressure volume loops. The left ventricular pressure volume loops during normal condition (blue) and after release the temporary occlusion of vena cava (red) to calculate Emax (black) and Tau (green). The load independent indices (Emax and Tau) are better indicators of ventricular contractility. The pressure volume loops were obtained from a pig of the Ischemia+TMR+Cell group during the final hemodynamic evaluation.

\subsection{Pathologic and Histologic Evaluations}

Every heart was sectioned from apex to base at $2.5 \mathrm{~mm}$ thickness. Each section was used to obtain color digital image for the determination of total left ventricular and scar volumes. Relative infarct volumes were quantified on the original photographs using threshold and measuring features of ImageJ.

The images were aligned and ordered to form an image stack. The image stacks were converted to DICOM format using Image J NIH public domain software and imported into open source OsiriX Medical Imaging Software loaded on an Apple G5 computer. Images were reconstructed using the 3D surface rendering (Fig. 4) or the 3D multiplanar projection MPR modes (Fig. 5). Tissue sections were observed under a confocal microscope for GFP labeled tissue.

\subsection{Regional Myocardial Blood Flow}

Colored microspheres $\left(15 \mu \mathrm{m}\right.$ diameter, $\sim 3 \times 10^{6}$ spheres/ml; Interactive Medical Technologies Ltd., Irvine, $\mathrm{CA}$ ) in $2 \mathrm{ml}$ of saline containing $14 \%$ sucrose and $0.01 \%$ Tween 80 were injected into the left atrium. Arterial blood samples were drawn at $15 \mathrm{ml} / \mathrm{min}$ using a syringe pump started at $5 \mathrm{sec}$ before microsphere injection for a total duration of $65 \mathrm{sec}$. The regional myocardial blood flow $(\mathrm{ml} / \mathrm{min} / \mathrm{g})$ was calculated as the published method [43]. The middle sections (three) from LAD perfusion area between the Prolene sutures (ischemic myocardium) and posterior

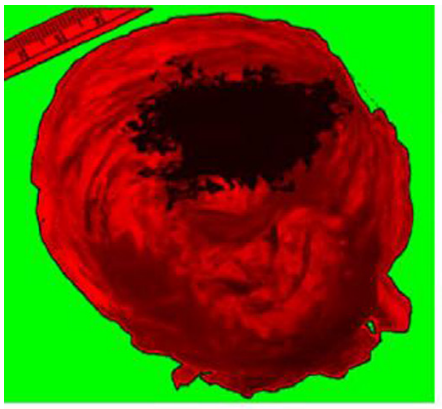

Ischemia + TMR

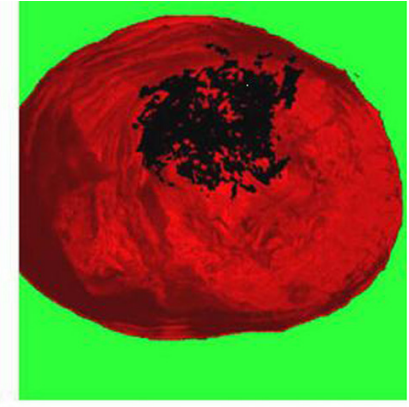

Ischemia + TMR + Cell
Fig. (4). 3-D reconstruction of the hearts. The Ischemia $+\mathrm{TMR}$ group has confluent scar $(18.3 \pm 2.5 \%$ of LV) while the Ischemia + TMR + Cell group has patchy scars $(5.1 \pm 0.8 \%$ of $L V)$.

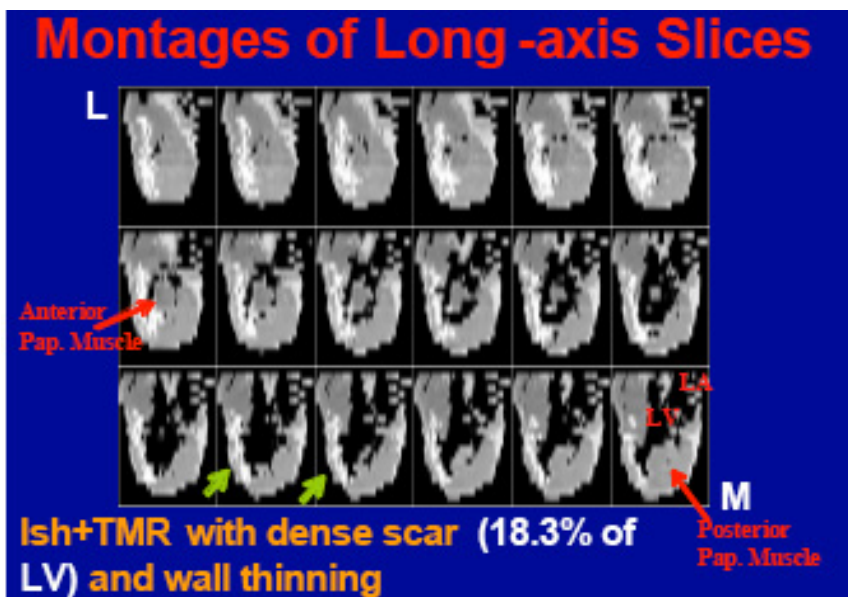

LV) and wall thinning

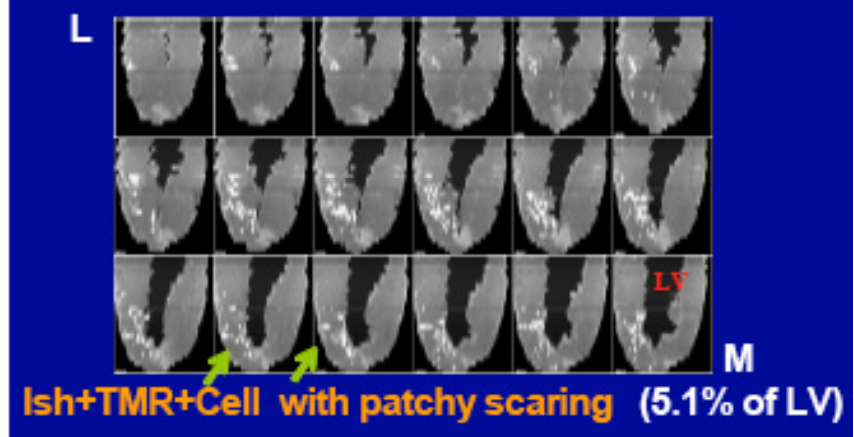

Fig. (5). 3-D multiplanar projection of the hearts. The Ish (Ischemia)+TMR heart showing wall thinning with confluent scar (green arrows) while Ish $+\mathrm{TMR}+\mathrm{Cell}$ heart maintained normal LV geometry with patchy scaring (green arrows). $\mathbf{M}=$ Medial; $\mathbf{L}=$ Lateral; LV= Left Ventricle; LA = Left Atrium.

ventricular wall (normal myocardium) directly against the ischemia area were used. The ratio of regional myocardial blood flow was calculated by the following formula to obtain the normalized percent flow rate.

\section{Percent Flow Rate:}

Regional myocardial blood flow of ischemic myocardium X $100 \%$

Regional myocardial blood flow

of normal myocardium 


\subsection{Statistics}

All data were summarized for each group by the mean \pm SEM. Differences between study group means were assessed by analysis of variance and multiple comparison testing (least significant differences). At $\mathrm{P}<0.05$ was considered significant difference between groups. The SAS-PC software package was used for the analysis procedures.

\section{RESULTS}

\subsection{Surgical Outcomes}

Thirty two male mini-swine underwent muscle biopsy, instrumentation and placement of ameroid constrictor at the selected segment of left anterior descending coronary artery (first operation) to produce comparable ischemic areas. Three weeks later the pigs were randomly assigned to Ischemia (partial sternotomy), Ischemia + TMR (TMR plus serum free culture medium), Ischemia + Cell (intra myocardial injection of autologous satellite cells) and Ischemia + TMR + Cell (TMR plus autologous satellite cells) groups at eight pigs per group. There were no major perioperative complications related to all surgical procedures.

Although TMR and cell injection caused ectopic beats, the arrhythmias were resolved without intervention. Bleeding from laser channels was easily controlled by manual compression. One pig from the Ischemia group, two pigs from the Ischemia + TMR group, one pig from the Ischemia + Cell group and one pig from the Ischemia + TMR + Cell group died of sudden cardiac death at different times after the second operation. The data represent 27 pigs that survived the procedures.

\subsection{Histological Observations}

The ameroid constrictor gradually reduced the LAD blood flow and resulted in damaged myocardium which represented about $20 \%$ of the left ventricle. As shown by Figs. $(6,7)$, the scar area was dramatically reduced for the cell implantation groups as compared to the other groups. Histological sections of Cell groups revealed multiple viable islands of muscle tissue expressing GFP under confocal microscope (Fig. 8), suggesting the muscle tissue was developed from the implanted satellite cells.

\subsection{Regional Myocardial Blood Flow}

Myocardial blood flow at the end of our study was summarized by Fig. (9). The values were normalized to blood flow measured in the non-ischemic area to derive percent flow rate. The sections for ischemic area (anterior wall) and the non-ischemic area (posterior wall) were illustrated by Fig. (7). TMR did not significantly improve the myocardial blood flow while Cell and TMR+Cell almost restored myocardial blood flow to normal value. Reduced scar formation and improved blood perfusion are commonly observed in clinical and experimental studies after cellular cardiomyoplasty following myocardial infarction.

\subsection{Hemodynamic Functions}

Other than left ventricular end diastolic pressures (Fig. 10), the end systolic pressures and developed pressures were not significantly different between groups. The ejection fractions were significantly higher while left ventricular end

\section{SCAR AREA}

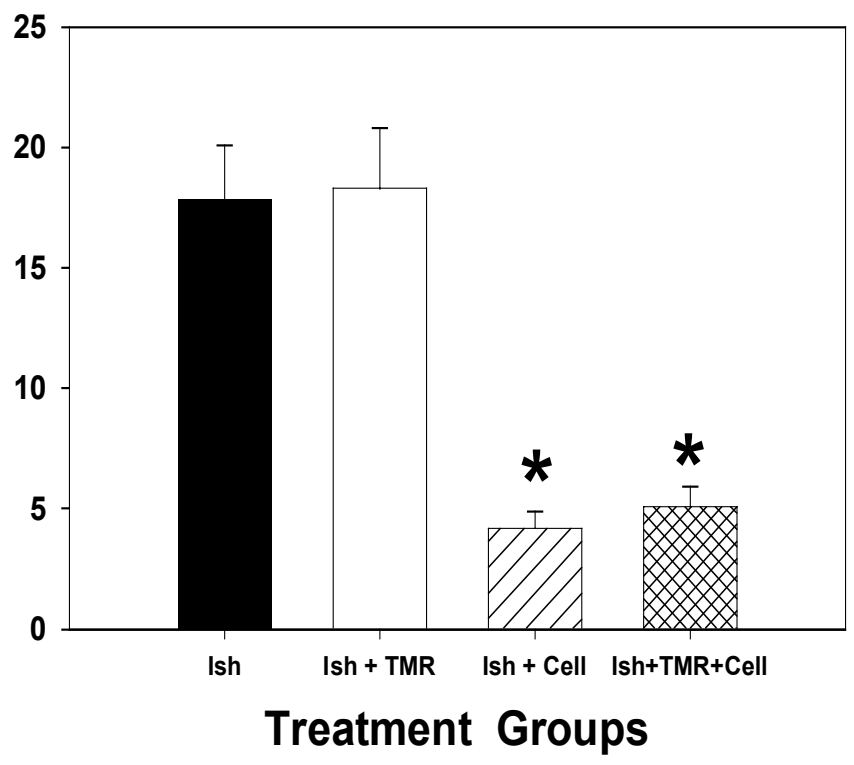

Fig. (6). Scar area as percent of left ventricle. Highly significant reduction of scar tissue $(\mathrm{p}<.01)$ after ischemic heart treated by Cell or TMR + Cell was observed. TMR alone did not reduce the scar area as compared to the Ischemia group. ${ }^{*}=\mathrm{P}<.01 v s$ the Ish and Ish + TMR groups. Ish = Ischemia; TMR $=$ Transmyocardial Laser Revascularization; $\mathbf{C e l l}=$ Cell Therapy.

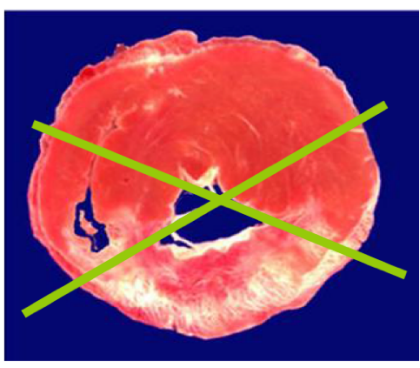

Ischemia



Ischemia + TMR

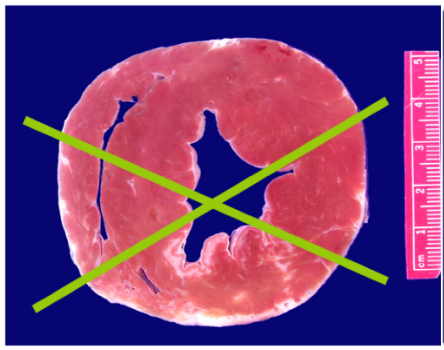

Ish + Cell

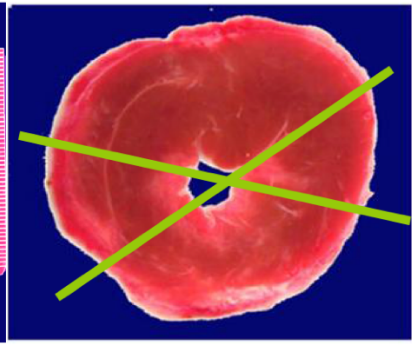

Ish +TMR + Cell
Fig. (7). Pathology of the hearts. Representative sections from a heart of each group showing the scar tissue. Dramatic reduction in scar areas were observed for the groups treated with autologous satellite cells. The two green lines divided the ischemic myocardium on anterior wall (marked between Polene sutures) and the normal myocardium from posterior wall that were used to determine regional blood flow. $\mathbf{I s h}=$ Ischemia; $\mathbf{T M R}=$ Transmyocardial Laser Revascularization; Cell $=$ Cell Therapy. 


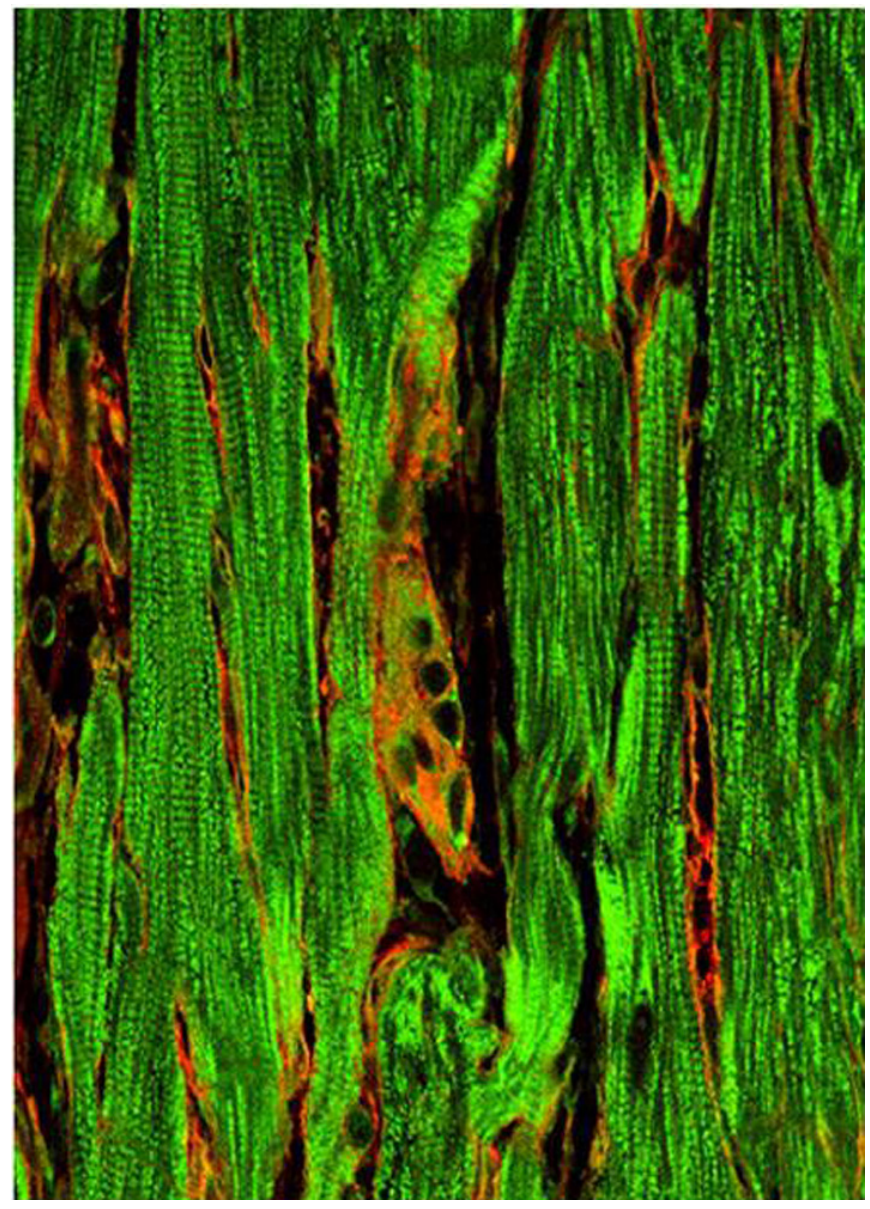

Fig. (8). Histology of myocardial sample form Ischemia+TMR+Cell group. Tissue sample from the ischemic area observed under a cofocal microscope revealed muscle tissue expressing green fluorescence protein that suggested the origin of muscle tissue was from the implanted cells (labeled with GFP). Original magnification $=600 \mathrm{X}$.

systolic and diastolic volumes were significantly lower in the cell treated groups; all of the other global hemodynamic functions were not different between treatment groups (Fig. 10). The \% wall thickening fraction changed from $7.8 \pm 0.4 \%$ to $3.8 \pm 0.4 \%$ at three weeks after ameroid constrictor application $(\mathrm{P}<0.01)$. At six weeks later only the cell treatment groups (7.1 \pm 1.1 and $6.8 \pm 1.0 \%)$ significantly improved $(\mathrm{P}<0.01)$ while the Ischemia $(5.2 \pm 0.7 \%)$ and Ischemia+TMR $(4.6 \pm 0.7 \%)$ groups were not significantly improved.

The average baseline \% segmental shortening fraction was $8.1 \pm 0.5 \%$ and significantly decreased to $3.9 \pm 0.6 \%$ at three weeks after ameroid constrictor installation. The \% segmental shortening fraction recovered to $4.7 \pm 1.8,3.9 \pm 1.2$, $6.7 \pm 1.7$ and $6.0 \pm 1.9 \%$ for the Ischemia, Ischemia+TMR, Ischemia + Cell, and Ischemia $+\mathrm{TMR}+$ Cell groups respectively. Although a clear recovery was observed for the cell implantation groups, the differences were not statistically significant.

\section{DISCUSSION}

Although both TMR and cellular cardiomyoplasty have demonstrated significant clinical benefit to the patients after treatment, the mechanisms remained to be elucidated. TMR is hypothesized to induce angiogenesis to improve perfusion of ischemic myocardium while cellular cardiomyoplasty will regenerate new muscle tissue to replace the damaged heart muscle. The hypothesis tested by this study is the combination of TMR and cellular cardiomyoplasty may induce both angiogenesis and myogenesis that will restore the chronic ischemic heart.

\section{Regional Myocardial Blood Flow}

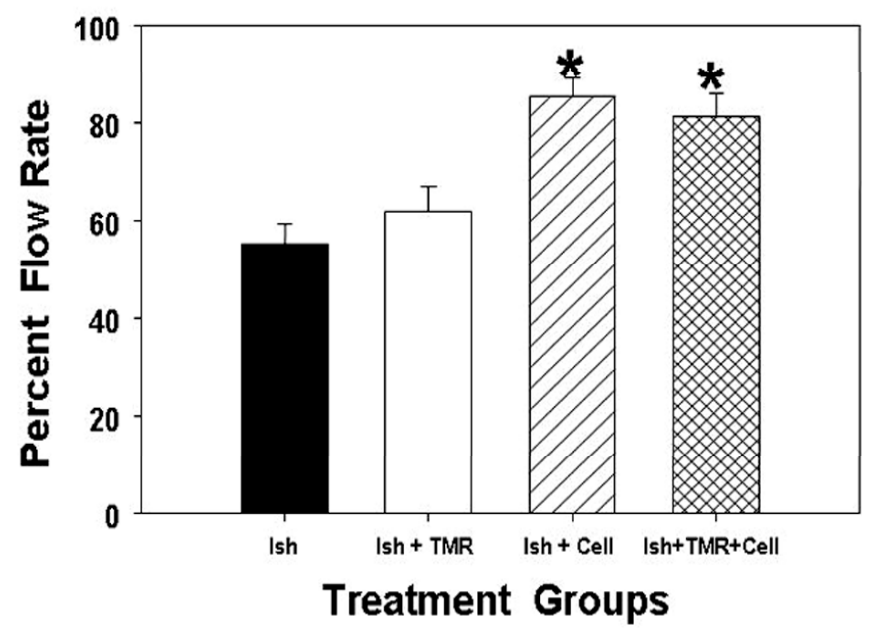

Fig. (9). Regional myocardial blood flow. Normalized regional myocardial blood flow showing significant better recovery of cell treated groups than TMR and Ischemia groups. A remote area [shown by Fig. (7)] not affected by any treatment form each heart was selected as a reference to derive the normalized regional myocardial percent flow rate. The normal myocardial blood flow is 1.1 $\pm 0.2 \mathrm{~mL} / \mathrm{g} / \mathrm{min} .{ }^{*}=\mathrm{P}<.05 v s$ the Ish and Ish + TMR groups. Ish $=$ Ischemia; $\mathbf{T M R}=$ Transmyocardial Laser Revascularization; $\mathbf{C e l l}=$ Cell Therapy.

Following TMR the laser channels were rapidly filled with fibrin thrombi before being invaded by granulation tissue which included a large amount of small vessels of various sizes. With the maturation of scar and contraction of fibrous tissue, most of the vessels regressed and lost their patency at six weeks after the procedure [44,45]. Fibrin thrombus is a potent stimulator of angiogenesis and laser induced injury to myocardium resulted in inflammatory responses that liberate numerous cytokines and growth factors. The TMR induced angiogenesis is most likely to be a nonspecific response of the myocardium to injury and has been well illustrated by pure mechanical injury studies [46-48].

The ischemic area marked with 6-0 Prolene sutures was obtained from each heart as shown by Fig. (7) by cutting a straight line from the epicardial Prolene sutures through the center of the heart and extended to the other end. The anterior samples and the posterior samples that divided by the green lines were used to determine the regional myocardial blood flow of the ischemic and normal myocardium respectfully. Using myocardium samples from the same heart to derive the normalized regional myocardial percent flow rate significantly reduced the variations between hearts. From our results TMR did not significantly improve the blood perfusion at the treated ischemic area using the chronic ischemic animal model. Our results agreed with most of the experimental studies when followed longer than 4 weeks after TMR using microspheres [7]. However, the current study 

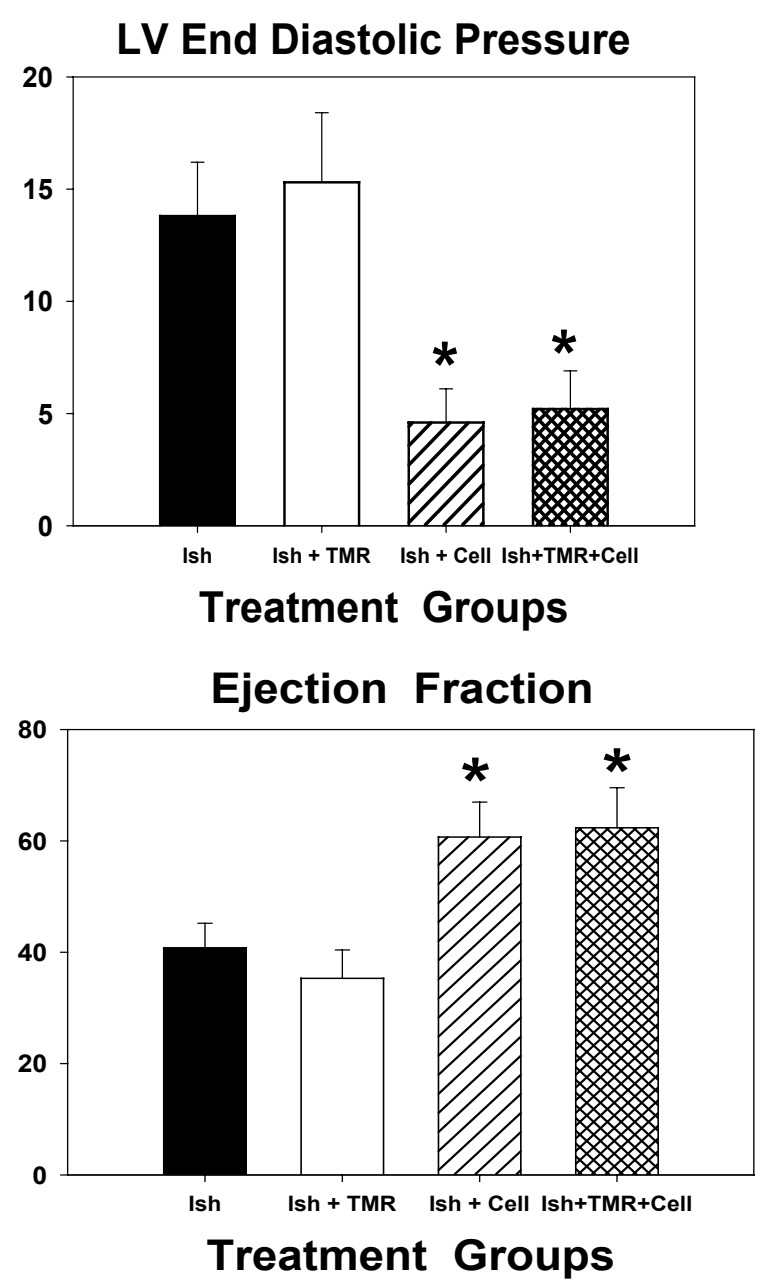

\section{End Diastolic Volume}

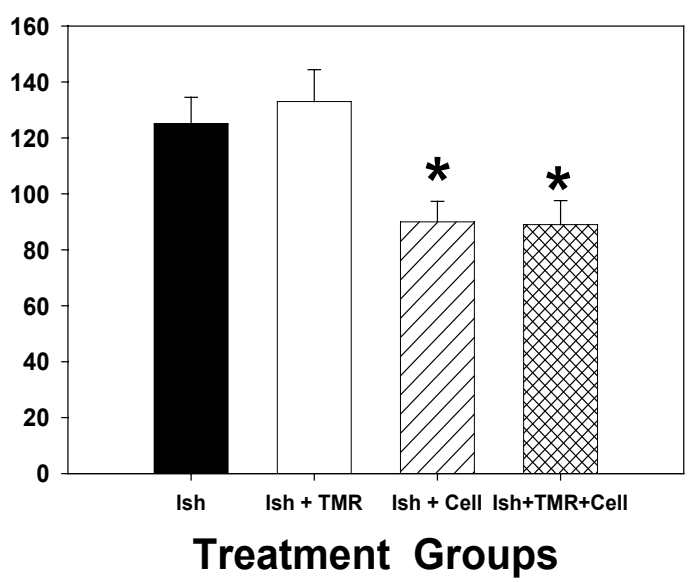

LV End Systolic Volume

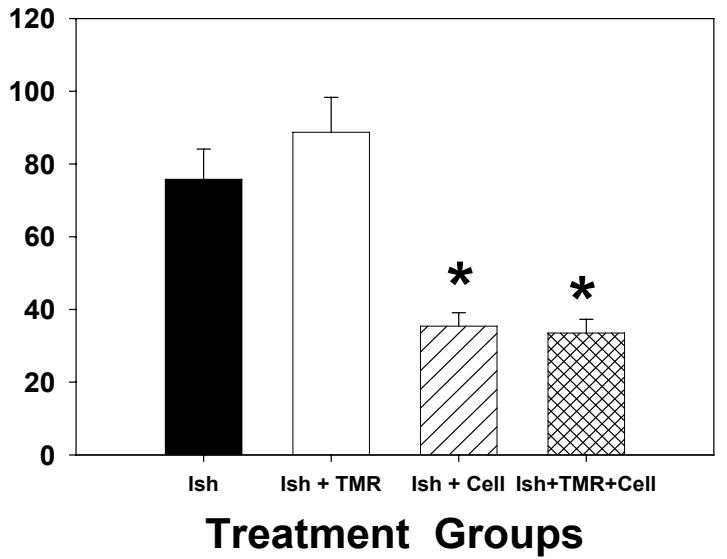

Fig. (10). Global hemodynamic functions. The left ventricular end diastolic pressure, ejection fraction, left ventricular end diastolic volume and end systolic volume, were all significantly improved by cell therapy. ${ }^{*}=\mathrm{P}<.05$ vs the Ish and Ish + TMR groups. $\mathbf{L V}=$ Left Ventricular; $\mathbf{I s h}=$ Ischemia; $\mathbf{T M R}=$ Transmyocardial Laser Revascularization; Cell $=$ Cell Therapy .

can not rule out the possibility of improving oxygen supply to the ischemic myocardium by diffusion or other mechanisms due to the enhanced circulation of adjacent coronary vessels resulted from the released angiogenic factors after TMR.

TMR significantly reduced severity of angina, improved quality of life, increased exercise tolerance, decreased hospitalization, and improved clinical status that justifies its clinical application either as a sole therapy or as an adjunct procedure $[16,49,50]$. Although angiogenesis and modification of cardiac nervous system [10-12] have been suggested as possible beneficial mechanisms, neither of them have concrete data to support their claims. The clear clinical advantages in angina alleviation during long-term follow-up support the continual therapeutic application.

Implantation of autologous stem cells significantly improved contractile functions, formation of muscle tissue, reduction of scar, and augmentation of blood perfusion after myocardial infarction in experimental and clinical studies [23-40]. Giving autologous stem cells into the TMR channels during the procedure has not been reported previously. In this study, only transplants using stem cells either alone or into the TMR channels resulted in beneficial outcomes. The highly significant decrease in end diastolic pressure and vol- ume in the cell implanted groups indicated the prevention of remodeling and possible heart failure after cell therapy. Cell therapy also maintained the ejection fraction at normal levels after chronic ischemic injury. A clear recovery in local contractile function was found of the cell treated groups for their $\%$ wall thickening fraction and \% segmental shortening fraction. In this study no objective improvement in cardiac function was evident following TMR alone, a result in agreement with published observations $[16,49,50]$. Only implantation of satellite cells was beneficial, results that are consistent with our previous experience. The favorable outcomes of cellular cardiomyplasty are confirmed from the results but TMR does not provide any additional advantages beyond stem cell therapy.

After myocardial infarction, the acute inflammatory reaction with inflammatory cell infiltration will be gradually subsided during the first week. This is followed by the granulation tissue formation for two to four weeks before scar maturation and remodeling. From the published results and our observations [51,52], between two to four weeks after myocardial infraction is the optimal time for cellular cardiomyoplasty. At three weeks after ameroid constrictor placement as performed in this study will give us the optimal timing for cell therapy. 
The replication-defective pFB-hrGFP retroviral supernatant was produced by transiently transfecting the packaging cells with the plasmid cDNA plus the gag-pol and env vectors. The supernatant does not produce any replicationcompetent retrovirus and the target cells after transfection also do not produce any replication-competent retrovirus as proved in our cell culture system. The humanized GFP (hrGFP) is low toxicity as compared to EGFP, that means it is possible to study gene expression without introducing unwanted artifacts into the experiment. Furthermore, the hrGFP labeled satellite cells after thoroughly sonication will not induce GFP expression in the myocardium. Together, the GFP labeled muscle tissue in Fig. (8) is most likely derived from the implanted satellite cells. If we can transfect the satellite cells with inducible gene that can render the developed muscle tissue inactive, we may be able to delineate the beneficial outcomes are due to prevention of ventricular remodeling or active contraction of the implanted cells.

\section{CONCLUSIONS}

Implantation of autologous satellite cells into TMR channels during the procedure is feasible. Cellular cardiomyoplsty alone or in conjunction with TMR achieved similar beneficial outcomes in reduced scar formation, prevented ventricular remodeling, enhanced blood perfusion, and preserved contractile function. TMR plus satellite cell implantation did not offer additional benefit over satellite cells alone. Further studies are warranted to delineate the possible beneficial mechanisms of the procedures.

\section{ACKNOWLEDGEMENTS}

This work was supported in part by grants from AHA Southeast Affiliate (Grant-In-Aid 0255009B) and National Institutes of Health, NHLBI (HL72138). The $\mathrm{CO}_{2}$ laser and related supplies were provided form PLC Medical Systems (Franklin, MA).

\section{REFERENCES}

[1] Mirhoseini M, Cayton MM. Revascularization of the heart by laser. J Microsurg 1981; 2(4): 253-60.

[2] Cooley DA, Frazier OH, Kadipasaoglu KA, et al. Transmyocardial laser revascularization: clinical experience with twelve-month follow-up. J Thorac Cardiovasc Surg 1996; 111(4): 791-7.

[3] Horvath KA, Cohn LH, Cooley DA, et al. Transmyocardial laser revascularization: results of a multicenter trial with transmyocardial laser revascularization used as sole therapy for end-stage coronary artery disease. J Thorac Cardiovasc Surg 1997; 113(4): 645-53.

[4] Tsang JC, Chiu RC. The phantom of "myocardial sinusoids": a historical reappraisal. Ann Thorac Surg 1995; 60(6): 1831-35.

[5] Kohmoto T, Fisher PE, Gu A, et al. Physiology, histology, and two week morphology of acute myocardial channels made with a $\mathrm{CO}_{2}$ laser. Ann Thorac Surg 1997; 63(5): 1275-83.

[6] Whittaker P. Transmyocardial revascularization: the fate of myocardial channels. Ann Thorac Surg 1999; 68(6): 2376-82.

[7] Bridges CR. Myocardial laser revascularization: the controversy and the data. Ann Thorac Surg 2000; 69(2): 655-62.

[8] Frazier OH, March RJ, Horvath KA. Transmyocardial revascularization with a carbon dioxide laser in patients with end-stage coronary artery disease. N Engl J Med 1999; 341(14): 1021-8.

[9] Allen KB, Dowling RD, Fudge TL, et al. Comparison of transmyocardial revascularization with medical therapy in patients with refractory angina. N Engl J Med 1999; 341(14): 1029-36.

[10] Al-Sheikh T, Allen KB, Straka SP, et al. Cardiac sympathetic denervation after transmyocardial laser revascularization. Circulation $1999 ; 100(2): 135-40$.

[11] Arora RC, Hirsch GM, Hirsch K, Armour JA. Transmyocardial laser revascularization remodels the intrinsic cardiac nervous sys- tem in a chronic setting. Circulation 2001; 104(12 Suppl 1): I11520.

[12] Asai T, Yamamoto S, Ishino K, et al. Time dependent regional myocardial denervatyion as a nonspecific response to trnasmyocadial laser revascularization. Ann Thorac Surg 2005; 80(4): 13629.

[13] Yamamoto N, Kohmoto T, Gu A, DeRosa C, Smith CR, Burkhoff D. Angiogenesis is enhanced in ischemic canine myocardium by transmyocardial laser revascularization. J Am Coll Cardiol 1998; 31(6): 1426-33.

[14] Hughes GC, Kypson AP, Annex BH, et al. Induction of angiogenesis after TMR: a comparison of holmium: YAG, $\mathrm{CO}_{2}$, and excimer lasers. Ann Thorac Surg 2000; 70(2): 504-9.

[15] Horvath KA. Transmyocardial laser revascularization. Curr Treat Options Cardiovasc Med 2004; 6(1): 53-9.

[16] Bridges CR. Guidelines for the clinical use of transmyocardial laser revascularization. Semin Thorac Cardiovasc Surg 2006; 18(1): 6873.

[17] Schneider J, Diegeler A, Krakor R, Walther T, Kluge R, Mohr FW. Transmyocardial laser revascularization with the holmium: YAG laser: loss of symptomatic improvement after 2 years. Eur J Cardiothorac Surg 2001; 19(2): 164-9.

[18] Allen KB, Dowling RD, Angell WW, et al. Transmyocardial revascularization: 5-year follow-up of a prospective, randomized multicenter trial. Ann Thorac Surg 2004; 77(4): 1228-34.

[19] Allen KB, Dowling RD, Schuch DR, et al. Adjunctive transmyocardial revascularization: five-year follow-up of a prospective, randomized trial. Ann Thorac Surg 2004; 78(2): 458-65.

[20] Horvath KA, Aranki SF, Cohn LH, et al. Sustained angina relief 5 years after transmyocardial laser revascularization with $\mathrm{CO}_{2}$ laser. Circulation 2001; 104(12 Suppl 1): I81-4.

[21] Hamawy AH, Lee LY, Samy SA, et al. Transmyocardial laser revascularization dose response: enhanced perfusion in a porcine ischemia model as a function of channel density. Ann Thorac Surg 2001; 72(3): 817-22.

[22] Mouli SK, Fronza J, Greene R, Robert ES, Horvath KA. What is the optimal channel density for transmyocareial laser revascularization? Ann Thorac Surg 2004; 78(4): 1326-31.

[23] Marelli D, Desrosiers C, el-Alfy M, Kao RL, Chiu RC. Cell transplantation for myocardial repair: an experimental approach. Cell Transplant 1992; 1(6): 383-90.

[24] Chiu RC, Zibaitis A, Kao RL. Cellular cardiomyoplasty: myocardial regeneration with satellite cell implantation. Ann Thorac Surg 1995; 60(1): 12-8.

[25] Kao RL, Chiu RC. In: Kao RL, Chiu RC, Eds. Satellite Cell Implantation. Austin, Landes; 1997: 129-62.

[26] Kao RL. In: Kipshidze NN, Serruys PW, Eds. Transplantation of satellite cells for myocardial regeneration. London, Martin Dunitz; 2004: 91-105.

[27] Taylor DA, Atkins BZ, Hungspreugs P, et al. Regenerating functional myocardium: improved performance after skeletal myoblast transplantation. Nat Med 1998; 4(8): 929-33.

[28] Scorsin M, Hagege A, Vilquin JT, et al. Comparison of the effects of fetal cardiomyocyte and skeletal myoblast transplantation on postinfarction left ventricular function. J Thorac Cardiovasc Surg 2000; 119(6): 1169-75.

[29] Agbulut O, Vandervelde S, Al Attar NA, et al. Comparison of human skeletal myoblasts and bone marrow-derived CD133 $3^{+}$progenitors for the repair of infracted myocardium. J Am Coll Cardial 2004; 44(2): 458-63.

[30] Menasche P, Hagege AA, Vilquin JT, et al. Autologous skeletal myobpast transplantation for severe postinfarction left ventricular dysfunction. J Am Coll Cardiol 2003; 41(7): 1078-83.

[31] Herreros J, Prosper F, Perez A, et al. Autologous intramyocardial injection of cultured skeletal muscle-derived stem cells in patients with non-acute myocardial infarction. Eur Heart J 2003; 24(22): 2012-20.

[32] Smits PC, van Geuns RJ, Poldermans D, et al. Catheter-based intramyocardial injection of autologous skeletal myoblasts as a primary treatment of ischemic heart failure: clinical experience with six-month follow-up. J Am Coll Cardiol. 2003; 42(12): 20639.

[33] Chachques JC, Acar C, Herreros J, et al. Cellular cardiomyoplasty: clinical application. Ann Thorac Surg 2004; 77(3): 1121-30.

[34] Siminiak T, Kalawski R, Fiszer D, et al. Autologous skeletal myoblast transplantation for the treatment of postinfarction myo- 
cardial injury: phase 1clinical study with 12 months of follow-up. Am Heart J 2004; 148(3): 531-7.

[35] Dib N, Michler RE, Pagani FD, et al. Safety and feasibility of autologous myoblast transplantation in patients with ischemic cardiomyopathy: four-year follow-up. Circulation 2005; 112(12): 1748-55.

[36] Zhang F, Yang Z, Chen Y, et al. Clinical cellular cardiomyoplasty: technical considerations. J Card Surg 2003; 18(3): 268-73.

[37] Zhang F, Yiang Z, Chen Y, et al. Autologous satellite cells transplantation to treat coronary heart disease. Stem Cell Cellular Therapy $2004 ; 2(1): 12-7$.

[38] Hagege AA, Marolleau JP, Vilquin JT, et al. Skeletal myoblast transplantation in ischemic heart failure: long-term follow-up of the first phase I cohort of patients. Circulation 2006; 114 (1 Suppl): I108-13.

[39] Dib N, Michler RE, Pagani FD, et al. Safety and feasibility of autologous myoblast transplantation in patients with ischemic cardiomyopathy: four-year follow-up. Circulation 2005: 112(12): 1748-55.

[40] Kao RL, Ganote CE, Pennington DG, Browder IW. In: Prakash S., Ed. Myocardial regeneration, tissue engineering and therapy. Cambridge, Woodhead Publishing Ltd. 2007: 349-65.

[41] Murry CE, Field LJ, Menasche P. Cell-based cardiac repair: reflections at the 10-year point. Circulation 2005; 112(20): 3174-83.

[42] Hawke TJ, Garry DJ. Myogenic satellite cells: physiology to molecular biology. J Appl Physiol 2001; 91(2): 534-51.

[43] Hale SL, Alker KJ, Kloner RA. Evaluation of nonradioactive, colored microspheres for measurement of regional myocardial blood flow in dogs. Circulation 1988; 78(2): 428-34.
[44] Roethy W, Yamamoto N, Burkhoff D. An examination of potential mechanisms underlying transmyocardial laser revascularization induced increases in myocardial blood flow. Semin Thorac Cardiovasc Surg 1999; 11(1): 24-8.

[45] Fisher PE, Khomoto T, DeRosa CM, Spotnitz HM, Smith CR, Burkhoff D. Histologic analysis of transmyocardial channels: comparison of $\mathrm{CO}_{2}$ and holmium: YAG lasers. Ann Thorac Surg 1997; 64(2): 466-72.

[46] Chu VF, Giaid A, Kuang JQ, et al. Angiogenesis in transmyocardial revascularization: comparison of laser versus mechanical punctures. Ann Thorac Surg 1999; 68(2): 301-7.

[47] Malekan R, Reynolds C, Narula N, Kelley ST, Suzuki Y, Bridges CR. Angiogenesis in transmyocardial laser revascularization. A nonspecific response to injury. Circulation 1998; 98(19 Suppl): II62-5

[48] Whittaker P, Rakusan K, Kloner RA. Transmural channels can protect ischemic tissue. Assessment of long-term myocardial response to laser- and needle-made channels. Circulation 1996; 93(1): 143-52.

[49] Horvath KA. Clinical results of sole therapy TMR treatment. Semin Thorac Cardiovasc Surg 2006; 18(1): 46-51.

[50] Allen KB. Transmyocardial laser revascularization as an adjunct to coronary artery bypass grafting. Semin Thorac Cardiovasc Surg 2006; 18(1): 52-7.

[51] Li RK, Mickle DA, Weisel RD, Rao V, Jia ZQ. Optimal time for cardiomyocyte transplantation to maximize myocardial function after left ventricular injury. Ann Thorac Surg 2001; 72(6): 1957-63.

[52] Kao RL, Zhang F, Yiang ZJ, Gao X, Li C. Cellular cardiomyoplasty using autologous satellite cells: from experimental to clinical study. Basic Appl Myol 2003; 13(1): 23-8. 